\title{
MODERASI FREE CASH FLOW TERHADAP FAKTOR-FAKTOR YANG MEMENGARUHI EARNINGS RESPONSE COEFFICIENT
}

\author{
Filbert Nathaniel \\ Rizka Indri Arfianti*
}

Program Studi Akuntansi, Kwik Kian Gie School of Business, Jl. Yos Sudarso Kav. 87, Jakarta 14350

\begin{abstract}
Financial statements are the information used by investors and stakeholders for consideration of decision making. One of important information is earnings. Quality earnings information can be relied on by users to predict the company's performance in the future. Earnings response coefficient (ERC) is a variable that measures the level of market reaction to the publication of earnings. Increasingly high market reaction means the earnings are qualified. But many other informations that affects ERC, the increase in earnings is not always followed by an increase of market reaction. In this research, the other informations are leverage, earnings persistence, size, and growth with free cash flow $(F C F)$ as a moderating size and growth. The Sample of this research are 31 LQ45 companies which are listed in IDX period 2015-2017. Sampling techniques to be used is the Non-Probability Sampling technique with Judgement Sampling Method. Data analysis method which is used in this research is Structural Equation Model in WarpPls 5.0. The results inner model and overallfit test are fulfilled. The conclusion showed that the leverage, size, and growth hasn't affected the ERC, and free cash flow is not able to strengthen influence growth on ERC. However, earnings persistence has affected positively on ERC and free cash flow is able to strengthen influence size on ERC.
\end{abstract}

Keywords: Earnings Response Coefficient, Leverage, Earnings Persistence, Size, Growth, Free Cash Flow

\begin{abstract}
Abstrak
Laporan keuangan merupakan informasi yang digunakan oleh investor dan pemangku untuk pertimbangan pengambilan keputusan. Salah satu informasi yang penting adalah informasi laba. Informasi laba yang berkualitas dapat diandalkan oleh pengguna untuk memprediksi kinerja perusahaan di masa depan. Earnings response coefficient (ERC) adalah variabel yang mengukur tingkat reaksi pasar atas publikasi laba. Reaksi pasar yang semakin tinggi artinya laba yang dipublikasikan berkualitas. Namun terdapat banyak informasi lain yang memengaruhi ERC, sehingga kenaikan laba tidak selalu diikuti dengan kenaikan tingkat reaksi pasar. Dalam penelitian ini informasi lain yang digunakan adalah leverage, earnings persistence, growth, dan size dengan free cash flow (FCF) memoderasi size dan growth. Sampel penelitian ini terdiri dari 31 perusahaan LQ45 yang terdaftar di BEI periode 2015-2017. Teknik pengambilan sampel yang dilakukan adalah NonProbability Sampling dengan menggunakan metode judgement sampling. Teknik analisis data yang digunakan dalam penelitian ini adalah Structural Equation Model dengan menggunakan WarpPLS 6.0. Hasil pengujian inner model, dan overall fit semuanya terpenuhi. Simpulan penelitian ini menunjukkan bahwa leverage, size growth tidak terbukti berpengaruh terhadap ERC, dan FCF tidak terbukti memperkuat pengaruh growth terhadap ERC. Earnings persistence terbukti berpengaruh positif terhadap ERC, dan FCF terbukti memperkuat pengaruh size terhadap ERC.
\end{abstract}

Kata Kunci: Koefisien Respon Laba, Leverage, Persistensi Laba, Ukuran, Pertumbuhan, Arus Kas Bebas

*Alamat kini: Institut Bisnis dan Informatika Kwik Kian Gie, Jl. Yos Sudarso Kav. 87, Jakarta 14350
Penulis untuk Korespondensi: Telp. (021) 65307062 Ext. 708, Email: rizka.indri@ kwikkiangie.ac.id 


\section{Pendahuluan}

Para investor umumya akan melihat laporan keuangan perusahaan untuk menentukan apakah kinerja perusahaan tersebut baik atau buruk. Laporan keuangan merupakan salah satu sumber informasi keuangan yang diberikan oleh perusahaan kepada publik terutama pada para investor dan para pemangku lainnya. Laporan keuangan diyakini, dapat memberikan informasi, mengenai posisi keuangan, kinerja manajemen, dan perubahan keuangan pada sebuah perusahaan yang relevan bagi para investor dalam rangka pengambilan keputusan.

Salah satu ukuran kinerja perusahan yang dapat dilihat dari laporan keuangan adalah laba yang dimiliki perusahaan pada periode tertentu. Laba perusahaan yang meningkat dari tiap periodenya akan diperhatikan oleh pihak eksternal perusahaan khususnya para investor modal. Kondisi yang dialami BEI juga akan semakin memicu pula para investor untuk lebih selektif dalam berinvestasi (Sandi, 2013)

Febrianto dan Widiastuty (2005) membuktikan adanya hubungan sangat erat antara laba perusahaan dengan return saham secara searah. Besaran yang menunjukkan pengukuran kekuatan hubungan antara return saham dan laba perusahaan disebut earnings response coefficient.

Penelitian mengenai earnings response coefficients berguna dalam analisis fundamental oleh investor dimana dalam model penelitian digunakan untuk menentukan reaksi pasar atas informasi laba suatu perusahaan (Susanto, 2012). Reaksi yang diberikan akan tergantung dari kualitas dan kredibilitas infromasi laba tersebut. Tinggi atau rendah earnings response coefficients tergantung dari good news atau bad news yang terkandung dalam laba (Arfan dan Antasari, 2008). Rendahnya earnings response coefficients menunjukkan bahwa laba kurang informatif untuk melakukan keputusan ekonomi (Murwaningsari, 2008).

Umumnya dalam mengetahui kualitas laba yang baik, dapat diukur dengan menggunakan earnings response coefficient yang merupakan bentuk pengukuran kandungan informasi dalam laba. Penelitian earnings response coefficient merupakan perkembangan penelitian informasi laba yang difokuskan untuk melihat seberapa jauh respons pasar terhadap infromasi laba akuntansi (Rofika, 2015).

Fenomena kenaikan laba tidak selalu diikuti dengan perubahan harga saham yang positif yang artinya harga saham mengalami pertumbuhan, begitu juga dengan sebaliknya pada saat laba mengalami penurunan maka harga saham tidak selalu diikuti dengan penurunan. Hal tersebut menunjukkan bahwa investor, kreditor, dan para pemangku lainnya tidak hanya melihat informasi laba saja sebagai esensi dasar dalam pengambilan keputusan finansial namun terdapat informasiinformasi lainnya (Mulyani, Asyik, dan Andayani, 2007).

Berbagai penelitian terdahulu yang terkait dengan earnings response coefficient masih terdapat perbedaan hasil penelitian. Namun, dengan mengetahui faktor-faktor yang memengaruhi earnings response coefficient tersebut, maka dapat diketahui informasi mengenai kemungkinan besar kecilnya harga saham atas informasi laba dari suatu perusahaan (Susanto, 2012).

Leverage adalah menunjukkan proporsi atas pemakaian utang membiayai investasinya. Perusahaan dengan leverage yang tinggi berarti perusahaan menggunakan hutang dan kewajiban lainnya untuk membiayai asset dan berisiko lebih tinggi dibandingkan perusahaan dengan leverage yang lebih rendah (Wijayanti, 2013). Jika terjadi peningkatan laba pada suatu perusahaan maka yang diuntungkan adalah debtholders daripada pemegang saham, sebab perusahaan akan mengutamakan pembayaran hutang kepada debtholders daripada pembagian dividen kepada para pemegang saham (Mulyani et al, 2007).

Earnings persistence juga memengaruhi earnings response coefficient. Earnings persistence atau persistensi laba menjelaskan kemampuan perusahaan untuk mempertahankan jumlah laba yang diperoleh saat ini sampai masa mendatang (Jaswadi, 2004). Hasil penelitian Kim et al. (2002), Mulyani et al. (2007), Murwaningsari (2008), dan Lumantobing dan Arfianti (2009) menunjukkan bahwa earnings persistence berpengaruh positif terhadap earnings response coefficient.

Firm size (ukuran perusahaan) secara langsung akan mencerminkan tinggi rendahnya aktivitas operasi maupun investasi perusahaan. Dalam Penelitian Mulyani et al. (2007) 
menemukan bahwa ukuran perusahaan memberikan pengaruh positif signifikan terhadap earnings response coefficient.

Growth (pertumbuhan perusahaan) memiliki pertumbuhan margin, laba, dan penjualan yang tinggi (Arfan dan Antasari, 2008). Adapun pertumbuhan perusahaan juga dapat diukur dengan pertumbuhan total aset. Pertumbuhan perusahaan dapat mempengaruhi earnings response coefficient. Hal ini sesuai dengan temuan-temuan sebelumnya yang menunjukkan bahwa pertumbuhan perusahaan berpengaruh positif terhadap earnings response coefficient (Collins dan Kothari 1998; Arfan dan Antasari, 2008).

Salah satu jenis informasi lain yang dapat digunakan oleh para pemakai laporan keuangan adalah free cash flow atau arus kas bebas. Asnawi dan Wijaya (2015) menyatakan bahwa free cash flow merupakan besaran kas yang tersedia di perusahaan yang dapat dibagikan sebagai dividen kepada pemegang saham tanpa mengganggu jalannya operasi perusahaan.

Arfan dan Yani (2011) menunjukkan bahwa free cash flow memperkuat pengaruh ukuran perusahaan dan pertumbuhan perusahaan terhadap earnings response coefficient. Jika manajer lebih mengutamakan nilai perusahaan, artinya manajer mengutamakan kesejahteraan pemegang saham sehingga investor akan lebih merespons informasi laba yang dipublikasikan oleh perusahaan besar yang memiliki jumlah arus kas bebas yang tinggi dibandingkan dengan yang dipublikasikan oleh perusahaan kecil. Dengan demikian dapat dikatakan bahwa dengan adanya informasi arus kas bebas akan memperkuat pengaruh antara ukuran perusahaan dan pertumbuhan perusahaan terhadap earnings response coefficient.

Penelitian ini bertujuan untuk mencari bukti empiris pengaruh leverage, earnings persistence, size, dan growth terhadap earnings response coefficient dengan free cash flow sebagai moderasi size dan growth

\section{Telaah Pustaka}

\section{Teori Keagenan}

Menurut Jensen dan Meckling (1976) teori agensi adalah Hubungan keagenan merupakan sebuah kontrak antara pemegang saham (principal) dan manajemen (agen) dimana prinsipal memberikan wewenang kepada agen untuk melakukan suatu keputusan yang terbaik untuk kepentingan principal. Agen selaku yang menjalankan usaha tentunya akan memiliki informasi yang lebih banyak mengenai perusahaan sedangkan principal akan memiliki informasi yang lebih sedikit. Jika agen dan principal selalu berupaya memaksimalkan kepentingan masing-masing dan memiliki kepentingan yang saling bertentangan maka mungkin saja dapat memunculkan kepercayaan bahwa agen tidak akan selalu bertindak sesuai keinginan principal. Eisenhardt (1989) mengatakan bahwa teori keagenan memiliki penekanan untuk mengatasi dua permasalahan utama keagenan. Masalah pertama adalah perbedaan keinginan dan tujuan dari principal dan agen. Masalah kedua adalah masalah pembagian risiko yang muncul saat agen dan prinsipal memiliki definisi yang berbeda mengenai risiko.

\section{Teori Signaling}

Menurut Jaswadi (2004) Teori signaling dalam akuntansi salah satu fungsinya adalah untuk menilai adanya informasi privat yang mengindikasikan bahwa nilai perusahaan lebih tinggi dari yang terefleksi pada harga saham saat ini. Laba akuntansi yang diumumkan via statement keuangan merupakan salah satu signal himpunan dari informasi yang tersedia bagi pasar modal Suwardjono (2017:490). Upaya manajer dalam meningkatkan kemakmuran pemegang saham adalah dengan memberikan good news kepada pasar untuk meningkatkan harga saham. Untuk mentransfer news, manajer, dapat mendisclose secara langsung (Jaswadi, 2004).

\section{Teori Efisiensi Pasar}

"Suatu pasar sekuritas dikatakan efisien jika harga-harga sekuritas "mencerminkan secara penuh" informasi yang tersedia (a security market is efficient if securities prices "fully reflect" the information available)." Menurut (Hartono, 2017:607-610) terdapat tiga bentuk dari efisiensi pasar, yaitu bentuk lemah (weakform), bentuk setengah kuat (semi strong-form), dan bentuk kuat (strong-form). Jenis ini dibedakan menjadi berdasarkan ketersediaan informasi pasar. Bentuk semi strong form 
merupakan bentuk pasar yang paling relevan dengan keadaan pasar saham di Bursa Efek Indonesia.

\section{Earnings Response Coefficient}

Menurut Scott (2015:163) Earning Response Coefficient (ERC) mengukur seberapa besar abnormal return saham dalam merespons unexpected earnings yang dilaporkan oleh perusahaan dalam mengeluarkan sekuritas tersebut. Sedangkan menurut Suwardjono (2017:493) ERC adalah "Kepekaan return saham terhadap setiap rupiah laba atau laba kejutan." Paramita dan Hidayanti (2013) juga mendefinisikan earnings response coefficient sebagai reaksi investor atas laba yang diumumkan (published) oleh perusahaan. Reaksi ini mencerminkan respons atas kualitas dari laba yang dilaporkan perusahaan. Tinggi rendahnya ERC sangat ditentukan kekuatan respons yang tercermin dari good news atau bad news yang terkandung dalam laba.

\section{Pengaruh Leverage terhadap Earnings Response Cofficient}

Perusahaan dengan leverage tinggi berarti perusahaan menggunakan utang dan kewajiban lain untuk membiayai aset dan berisiko lebih tinggi daripada perusahaan yang memiliki leverage yang lebih rendah. Hal ini sesuai dengan konflik pada teori agensi dan teori signaling di mana perusahaan lebih mengutamakan kepentingan manajemen dalam perusahaan dari pada kepentingan yang menyejahterakan pemegang saham (principal) dan informasi leverage yang tinggi merupakan sinyal bad news. Sehingga dengan adanya leverage yang tinggi tingkat reaksi pasar akan menurun.

Ha1 : Leverage berpengaruh negatif terhadap earnings response coefficient

\section{Pengaruh Earnings Persistence terhadap Earnings Response Cofficient}

Earnings persistence atau persistensi laba mencerminkan kualitas laba perusahaan dan menunjukkan bahwa perusahaan dapat mempertahankan laba dari waktu ke waktu bukan hanya karena suatu peristiwa tertentu. Semakin permanen perubahan laba dari waktu ke waktu maka semakin tinggi earnings response coefficient. Hal tersebut menunjukkan bahwa laba yang diperoleh perusahaan tersebut dapat meningkat secara terus menerus ataupun stabil dimasa yang akan datang yang memberikan signal yang baik (good news) kepada para investor.

$\mathrm{Ha} 2$ : Earnings persistence berpengaruh positif terhadap earnings response coefficient

\section{Pengaruh Size terhadap Earnings Response Cofficient}

Size merupakan variabel untuk mengukur seberapa besar atau kecilnya perusahaan Perusahaan besar dianggap mampu untuk terus meningkatkan kinerja perusahaannya dengan berupaya meningkatkan kualitas labanya. Semakin banyak informasi tersedia mengenai aktivitas perusahaan besar, semakin mudah bagi pasar untuk menginterpretasikan informasi dalam laporan keuangan, pengaruh laba terhadap harga saham menjadi lebih tinggi

Ha3 : Size berpengaruh positif terhadap earnings response coefficient

\section{Pengaruh Growth terhadap Earnings Response Cofficient}

Perusahaan yang memiliki tingkat pertumbuhan pesat cenderung lebih mendapat respons oleh investor dari pada perusahaan yang memiliki pertumbuhan lambat. Perusahaan yang terus menerus tumbuh akan lebih mudah memperoleh modal yang merupakan salah satu sumber pertumbuhan pendapatan perusahaan. Jadi, dengan meningkatnya pertumbuhan perusahan akan meningkatkan earnings perusahaan.

Ha4 : Growth berpengaruh positif terhadap earnings response coefficient

\section{Pengaruh Free Cash Flow terhadap hubungan antara Size dengan Earnings Response Coefficient}

Investor akan lebih merespons informasi laba yang dipublikasikan oleh perusahaan besar yang memiliki jumlah free cash flow yang tinggi dibandingkan dengan yang dipublikasikan oleh perusahaan kecil. Sehingga semakin besar free cash flow yang dibayarkan kepada pemegang saham, mengindikasikan besarnya perhatian manajer sebagai agen pemegang saham pada investor. Pemberian informasi tambahan melalui free cash flow bertujuan untuk memperkuat 
akuntabilitas perusahaan terhadap investor sebagai elemen yang dapat diterima sebagai sinyal yang baik untuk investor.

Ha5 : Free cash flow memperkuat pengaruh size terhadap earnings response coefficient

\section{Pengaruh Free Cash Flow terhadap hubungan antara Size dengan Earnings Response Coefficient}

Free cash flow merupakan uang kas yang tersedia bagi perusahaan untuk mendukung kewajiban terhadap pemberi dana jangka panjang, yaitu pembayaran untuk mendukung kewajibannya seperti pembayaran bunga, dividen, dan kemungkinan pelunasan hutang. pertumbuhan perusahaan yang tinggi akan lebih direspons pasar lebih tinggi. Hal ini dikarenakan perusahan yang bertumbuh akan memperbesar size dimana ukuran yang besar dapat memberikan informasi yang lebih menjanjikan kepada investor. Sehingga dengan adanya informasi tambahan free cash flow, investor dapat mengharapkan pembagaian dividen di mana informasi tersebut merupakan sinyal baik.

Ha6 : Free cash flow memperkuat pengaruh Growth terhadap earnings response coefficient

\section{Gambar 1.0}

\section{Model Konseptual}

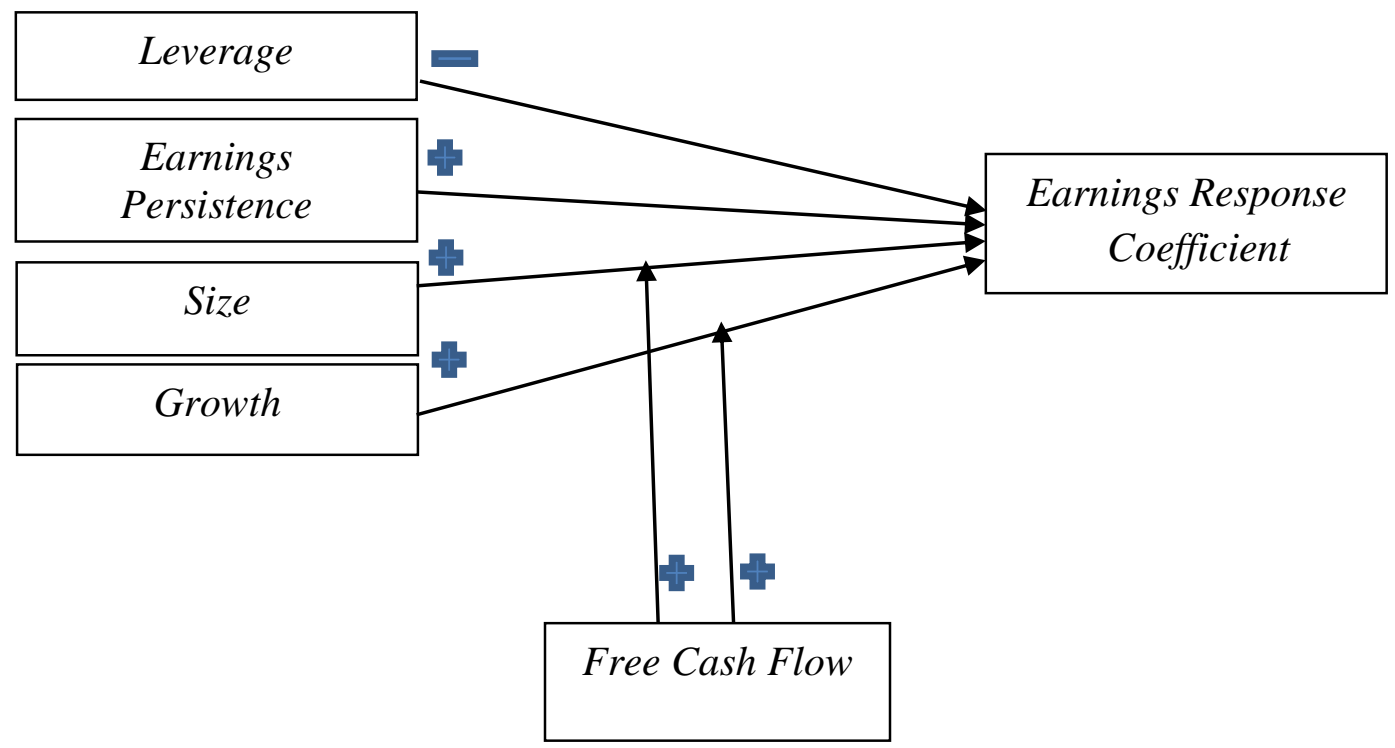

\section{Metode Penelitian}

Objek penelitian yang digunakan dalam penelitian ini adalah perusahaan Indeks LQ45 yang terdaftar di Bursa Efek Indonesia periode waktu 2015 hingga 2017. Perusahaan LQ45 merupakan perusahaan yang memiliki saham yang aktif dan likuid diperdagangkan dibandingkan dengan perusahaan lainnya. Sampel perusahaan yang digunakan adalah perusahaan yang mempublikasikan laporan keuangan tahunan untuk periode 31 Desember 2015-2017, dan telah diaudit oleh auditor eksternal.

\section{Variabel Penelitian}

\section{Earnings Response Coefficient}

Earnings response coefficient (ERC) adalah reaksi atas laba diumumkan oleh perusahaan. ERC mengukur seberapa besar abnormal return saham dalam merespon unexpected earnings yang dilaporkan perusahaan yang mengeluarkan sekuritas tersebut (Scott, 2015:163). Model pengukuran ERC penelitian ini mengacu pada Mulyani et al., (2007). Nilai ERC didapat dari hasil regresi persamaan 3.1 dengan menggunakan program SPSS 25.0.

$$
\mathrm{CAR}_{\mathrm{it}}=\alpha_{0}+\alpha_{1} \mathrm{UE}+\varepsilon_{\mathrm{it}}
$$


Keterangan:

$\mathrm{CAR}_{\mathrm{it}}=$ Cumulative abnormal return perusahaan i selama periode jendela (windows period) \pm 5 hari dari tanggal publikasi laporan keuangan.

$\alpha_{0} \quad=$ Konstanta dalam model regresi

$\alpha_{1}=$ Koefisien respons laba atau earnings response coefficient (ERC)

$\mathrm{UE}_{\mathrm{it}}=$ Unexpected Earnings perusahaan i pada periode $\mathrm{t}$

$\varepsilon_{\text {it }} \quad=$ Error

Untuk mencari nilai ERC atau $\alpha_{1}$ dengan menggunakan rumus 3.1 , perlu dicari terlebih dahulu nilai Cumulative Abnormal Return (CAR) dan Unexpected Earnings (UE).

a. Cumulative Abnormal Return (CAR)

CAR dalam penelitian ini dihitung dengan menggunakan market adjusted model yang mengacu pada penelitian Lumantobing dan Arfianti (2012). Perhitungan CAR menggunakan metode studi peristiwa yaitu periode jendela 11 hari, yaitu lima hari sebelum dan lima hari sesudah tanggal publikasi laporan keuangan serta satu hari pada saat tanggal publikasi laporan keuangan. Persamaannya adalah sebagai berikut.

$\mathrm{CAR}_{\mathrm{it}(-5,+5)}=\Sigma_{-5}^{+5} A R_{i t}$

$\mathrm{AR}_{\mathrm{it}}=\mathrm{R}_{\mathrm{it}}-\mathrm{Rm}_{\mathrm{it}}$

Keterangan

$\mathrm{CAR}_{\mathrm{it}(-5,+5)}=$ Cumulative abnormal return perusahaan i selama periode jendela

\pm 5 hari dari tanggal publikasi laporan keuangan

$\mathrm{AR}_{\mathrm{it}}=$ Abnormal return perusahaan i pada hari $\mathrm{t}$

$$
\begin{array}{ll}
\mathrm{R}_{\mathrm{it}} & =\text { Return sesungguhnya } \\
& \text { perusahan i pada hari } \\
& \mathrm{t} \\
\mathrm{RM}_{\mathrm{t}} & =\begin{array}{l}
\text { Return pasar pada } \\
\text { hari } \mathrm{t}
\end{array}
\end{array}
$$

Actual Return

$$
\mathrm{R}_{\mathrm{it}}=\frac{\mathrm{P}_{\mathrm{it}}-\mathrm{P}_{\mathrm{it}-1}}{\mathrm{P}_{\mathrm{it}-1}}
$$

Keterangan:

$\mathrm{R}_{\mathrm{it}}=$ Return individu sesungguhnya perusahaan I pada periode (hari) $t$

$$
\begin{aligned}
& \mathrm{P}_{\mathrm{it}} \quad \begin{array}{cr}
\text { Harga } \\
\text { penutupan }
\end{array} \\
& \begin{array}{r}
\text { saham } \\
\text { price) perusahaan } \mathrm{I}
\end{array} \\
& \text { pada periode } \\
& \text { (hari) } \mathrm{t}
\end{aligned}
$$

$$
\begin{aligned}
& \text { Market Return } \\
& \mathrm{Rm}_{\mathrm{t}}=\frac{\mathrm{IHSG}_{\mathrm{t}}-\mathrm{IHSG}_{\mathrm{t}-1}}{\mathrm{IHSG}_{\mathrm{t}-1}}
\end{aligned}
$$

Keterangan:

$\mathrm{Rm}_{\mathrm{t}}=$ Return pasar pada periode (hari) $\mathrm{t}$

$\mathrm{IHSG}_{\mathrm{t}}=$ Indeks harga saham gabungan pada periode (hari) $t$ $\mathrm{IHSG}_{\mathrm{t}-1}=$ Indeks harga saham gabungan pada periode (hari) $\mathrm{t}$ 1

Tanggal publikasi yang digunakan dalam penelitian ini merupakan tanggal laporan keuangan dipublikasikan oleh Bursa efek Indonesia yang tertera di website www.idx.co.id.

b. Unexpected Earnings (UE)

Unexpected Earnings (UE) dihitung dengan menggunakan selisih antara laba akuntansi sesungguhnya dengan laba akuntansi yang diekspektasi oleh pasar. Dalam hal ini earnings akan diukur dengan earnings before extraordinary items dan unexpected earnings dihitung dengan cara menggunakan model 
random walk seperti yang dilakukan oleh Mulyani, et al. (2007). Laba ekspektasi yang digunakan adalah laba periode sebelumnya. Perhitungannya adalah sebagai berikut

$$
\mathrm{UE}_{\mathrm{it}}=\frac{\left(\mathrm{EAT}_{\mathrm{it}}-\mathrm{EAT}_{\mathrm{it}-1}\right)}{\mathrm{EAT}_{\mathrm{it}-1}}
$$

Keterangan:

$\mathrm{UE}_{\mathrm{it}} \quad=$ Unexpected earnings perusahaan i pada periode $\mathrm{t}$

EPS $_{\mathrm{it}}=$ EAT perusahaan $\mathrm{i}$ pada periode $\mathrm{t}$

EPS $_{\text {it-1 }}=$ EAT perusahaan $\mathrm{i}$ pada periode $\mathrm{t}-1$

\section{Leverage}

Leverage adalah rasio total hutang terhadap total aset perusahaan yang menunjukkan kemampuan perusahaan memenuhi kewajiban jangka pendek maupun jangka panjangnya. Perusahaan dengan tingkat leverage yang tinggi berarti memiliki hutang yang lebih banyak dibandingkan modal (Susanto, 2012). Financial leverage memiliki beberapa rasio, dalam penelitian ini leverage dihitung dengan menggunakan debt to asset ratio.

Debt to Asset Ratio $(D A R)=\frac{\text { Total Liabilities }}{\text { Total Asset }}$

\section{Earnings Persistence}

Earnings Persistence (persistensi laba) adalah properti laba yang menjelaskan kemampuan perusahaan untuk mempertahankan jumlah laba yang diperoleh saat ini sampai masa mendatang (Lumantobing dan Arfianti, 2009). Persistensi akan diukur dari slope regresi atas perbedaan laba saat ini dengan laba sebelumnya (Chandarin, 2003 dalam Mulyani et al., 2007).

$X_{i t}=\alpha+\beta X_{i t-1}+\varepsilon$

Keterangan:

$$
\begin{array}{ll}
\mathrm{X}_{\mathrm{it}} & =\text { EAT perusahan } \mathrm{i} \\
\text { tahun } \mathrm{t} & \\
\mathrm{X}_{\mathrm{it}-1} & =\text { EAT perusahaan } \mathrm{i} \\
& \text { pada periode } \mathrm{t}-1
\end{array}
$$

Size

Total aktiva sebagai indikator besaran perusahaan karena semakin besar perusahaan, maka aktiva tetap yang dibutuhkan juga semakin besar (Arfan dan Yani, 2011). Menurut Hartono (2013:282) nilai total asset bernilai sangat besar dibandingkan dengan variabel lainnya, untuk itu variabel asset diperhalus menjadi log asset atau $\ln$ total asset.

$$
\text { Size }=\log (\text { Total Aktiva })
$$

\section{Growth}

Pertumbuhan perusahaan dalam hal ini diproksikan dengan pertumbuhan asset sesuai dengan teori pertumbuhan perusahaan Subramanyam (2014). Pertumbuhan aset didefinisikan sebagai presentase perubahan aset dari tahun ke tahun.

Pertumbuhan Perusahaan

$$
=\frac{\text { Total aset }_{t}-\text { Total aset }_{t-1}}{{\text { Total } \text { aset }_{t-1}}}
$$

\section{Free cash flow}

Free Cash Flow dalam penelitian ini diukur dengan menggunakan proksi yang digunakan Jones dan Sharma (2001) dalam Arfan dan Yani (2011) yaitu arus kas operasi (cash flow operation) dikurangi arus kas investasi (cash flow investment) dibagi dengan total aktiva (total assets).

Free Cash Flow
$=\frac{\text { Cash Flow Operation }- \text { Cash Flow Investment }}{\text { Total Assets }}$

\section{Teknik Pengumpulan Data}

Teknik pengumpulan data yang digunakan dalam penelitian ini adalah teknik observasi dengan pengamatan terhadap data sekunder pada laporan keuangan perusahaan manufaktur yang terdaftar di Bursa Efek Indonesia selama tahun 2015 sapai dengan tahun 2017. Data yang berhubungan dengan informasi perusahaan didapat dari Indonesian Capital Market Directory (ICMD) dan www.sahamok.com, laporan keuangan audited perusahaan dan tanggal publikasi laporan keuangan didapat dari Pusat Data Pasar Modal (PDPM) Kwik Kian Gie School of Business dan www.idx.co.id, serta 
harga saham perusahaan didapat dari www.yahoofinance.com.

\section{Teknik Pengambilan Sampel}

Teknik pengambilan sampel yang digunakan dalam penelitian ini adalah teknik NonProbability Sampling dengan menggunakan metode judgement sampling, yaitu teknik pengambilan sampel dengan pertimbangan tertentu (Sugiyono 2012: 122). Kriteria-kriteria yang ditetapkan peneliti dalam penelitian ini adalah sebagai berikut:

1. Tidak pernah diberhentikan/ delisting perdagangannya selama periode 2015-2017

2. Ketersediaan dan kelengkapan data selama periode 2015-2017

3. Perusahaan yang memiliki laporan keuangan yang berakhir 31 Desember dan disajikan dalam mata uang rupiah.

4. Laporan keuangan perusahaan harus memiliki rasio keuangan atau faktor-faktor untuk menghitung rasio keuangan secara lengkap.

\section{Teknik Analisis Data}

Penelitian ini menggunakan model persamaan struktural (Structural Equation Model) dengan menggunakan program WarpPLS 6.0 untuk pengembangan, pengujian model, dan pengolahan data. Berikut teknik analisis data,

\section{Statistik deskriptif}

Statistik deskriptif membahas informasi mengenai data yang diperoleh dalam suatu penelitian, antara lain informasi mengenai rata-rata (mean), nilai maksimum, nilai minimum, dan standar deviasi dari variabelvariabel yang diteliti (Ghozali, 2018:19). Analisis statistik deskriptif dengan menggunakan program SPSS 25.0.

\section{Evaluasi Model Struktural (Inner Model)}

Dalam menilai model struktural atau inner model dengan PLS, Goodness of Fit Model diukur menggunakan $R$-square variabel laten dependen dengan interpretasi yang sama dengan regresi; $Q$-Square predictive relevance untuk model struktural, mengukur seberapa baik nilai observasi dihasilkan oleh model dan juga estimasi parameternya (Jaya dan Sumertajaya, 2008).

Indikasi terjadinya problem collinearity pada PLS dapat dari indikasi sebagai berikut: a. $R$-Squared

Nilai $R$-Squared dapat dilihat dengan 3 tingkatan yaitu bila nilai $R$-Squared $\leq$ 0,25 maka dapat dikatakan model lemah, jika nilai $R$-Squared $\leq 0,45$ maka dapat dikatakan model moderate, dan nilai $R$ Squared $\leq 0,70$ maka dapat dikatakan model kuat. Semakin besar nilai ini, menunjukkan bahwa predictor.

b. Adjusted R-Squared

Nilai $R$-Squared dapat dilihat dengan 3 tingkatan yaitu bila nilai $R$-Squared $\leq$ 0,25 maka dapat dikatakan model lemah, jika nilai $R$-Squared $\leq 0,45$ maka dapat dikatakan model moderate, dan nilai $R$ Squared $\leq$ 0,70 maka dapat dikatakan model kuat. Semakin besar nilai ini, menunjukkan bahwa predictor model semakin baik dalam menjelaskan variance. Namun batas maksimal untuk nilai ini adalah 0,70 (Ghozali dan Latan, 2016:92).

\section{c. Q-Squared}

$Q$-Squared dilakukan untuk mengetau apakah model mempunyai predictive relevance atau tidak. Nilai $Q^{2}>0$ menunjukkan bahwa model mempunyai predictive relevance.

\section{Penilaian Overall fit}

Penilaian overall fit dilakukan untuk mengetahui apakah model SEM yang dibuat dapat diterima (fit). Indikator-indikator yang ada adalah sebagai berikut:

\section{a. Average Path Coefficient (APC)}

Nilai cut-off P-value untuk APC yang direkomendasikan sebagai indikasi model fit adalah $\leq 0,05$ dengan level signifikansi yang digunakan adalah $5 \%$ (Ghozali dan Latan, 2016:95).

\section{b. Average R-Squares (ARS)}

Nilai cut-off P-value untuk ARS yang direkomendasikan sebagai indikasi model fit adalah $\leq 0,05$ dengan level signifikansi yang digunakan adalah 5\% (Ghozali dan Latan, 2016:95).

c. Average Adjusted R-Squared (AARS)

Nilai cut-off P-value untuk AARS yang direkomendasikan sebagai indikasi model fit adalah $\leq 0,05$ dengan level signifikansi yang digunakan adalah 5\% (Ghozali dan Latan, 2016:95). 
d. Average Block VIF (AVIF)

Idealnya nilai yang direkomendasikan untuk AVIF harus $\leq$ 3,3 dengan asumsi kebanyakan konstruk/ variabel didalam model diukur dengan dua atau lebih indikator. Namun, nilai $\leq$ 5 masih dapat diterima asalkan kebanyakan konstruk/ variabel di dalam model diukur dengan indikator tunggal (Ghozali dan Latan, 2016:95).

e. Average Full Collinearity (AVFVIF) Idealnya nilai yang direkomendasikan untuk AFVIF harus $\leq$ 3,3 dengan asumsi kebanyakan konstruk/ variabel di dalam model diukur dengan dua atau lebih indikator. Namun, nilai $\leq$ 5 masih dapat diterima asalkan kebanyakan konstruk/ variabel di dalam model diukur dengan indikator tunggal (Ghozali dan Latan, 2016:95).

\section{f. Tenehaus GoF}

Gof memiliki tiga tingkatan nilai yaitu kecil apabila nilai $\mathrm{GoF} \geq 0,10$, sedang jika nilai $\mathrm{GoF} \geq 0,25$, dan besar jika nilai $\mathrm{GoF} \geq 0,36$ (Ghozali dan Latan, 2016:96).

g. Symspson's Paradox Ratio (SR)

Idealnya indeks harus sama dengan 1 atau jika nilai $S P R \geq 0,7$ masih dapat diterima yang artinya $70 \%$ atau lebih dari path didalam model bebas dari Sympson's paradox (Ghozali dan Latan, 2016:97).

\section{h. R-Squared Contribution Ratio (RSCR)}

Idealnya indeks harus sama dengan 1 atau jika nilai $\mathrm{RSCR} \geq 0,9$ masih dapat diterima yang berarti $90 \%$ atau lebih dari path di dalam model ini tidak berhubungan dengan kontrinusi $R$ Squared negatif (Ghozali dan Latan, 2016:98).

i. Statistical Suppression Ratio (SSR)

Nilai SSR dapat diterima jika memiliki nilai $\geq 0,7$ yang berarti $70 \%$ atau lebih dari path didalam model bebas dari statistical suppression (Ghozali dan Latan, 2016:98).

j. Nonliniear Bivariate Causality Direction Ratio (NLBCDR)

NLBCDR dapat diterima jika memiliki nilai $\geq 0,7$ yang berarti $70 \%$ atau lebih dari path yang berhubungan di dalam model penelitian ini mendukung untuk dibalik hipotesis dari hubungan kausalitas yang lemah (Ghozali dan Latan, 2016:98).

Berdasarkan hipotesis penelitian

maka model pemasaran struktural yang

terbentuk adalah sebagai berikut:

ERC $=$

$\beta_{0}+\beta_{1} L E V+\beta_{2} E P+\beta_{3} S I Z E+\beta_{4} G R W+\beta_{5} F C F * S I Z E+\beta_{6} F C$ $F^{*} \mathbf{G R W}+\varepsilon$

\section{Pengujian Hipotesis}

Pengujian hipotesis bertujuan untuk menjelaskan arah hubungan antara variabel independen, variabel dependen, dan variabel moderasi. Pengujian ini dilakukan dengan cara analisis jalur (path analysis) atas model yang telah dibuat. Teknik SEM dapat secara simultan menguji model struktural yang kompleks, sehingga dapat diketahui hasil analisis jalur dalam satu kali analisis regresi. Hasil korelasi antar konstruk diukur dengan melihat path coefficients dan tingkat signifikansinya yang kemudian dibandingkan dengan hipotesis penelitian.

Suatu hipotesis dapat diterima atau ditolak secara statistik dapat dihitung melalui tingkat signifikansinya. Tingkat signifikansi yang dipakai dalam penelitian ini adalah sebesar 5\%. Apabila tingkat signifikansi yang dipilih sebesar 5\% maka tingkat signifikansi atau tingkat kepercayaan 0,05 untuk menolak suatu hipotesis. Dasar pengambilan keputusan yaitu $p$-value $\leq 0,05$ hipotesis diterima sebaliknya $\geq$ hipotesis ditolak (Ghozali, 2016:346).

Tanda (arah) hubungan antar variabelvariabel laten mengindikasikan apakah hasil hubungan antara variabel-variabel tersebut memiliki pengaruh yang sesuai dengan yang dihipotesiskan.

\section{Hasil Dan Pembahasan}

\section{Uji Statistik Deskriptif}

Berdasarkan analisis statistik deskriptif penelitian ini menunjukkan bahwa terdapat 31 sampel yang digunakan dalam penelitian ini. Earnings response coefficient (ERC) memiliki nilai terendah $-0,57028$ yang dimiliki oleh PT Matahari Department Store Tbk. Dan nilai 
tertinggi sebesar 1,45192 yang dimiliki oleh PT Bank Central Asia Tbk. (BBCA) Hasil ini menggambarkan bahwa hubungan cumulative abnormal return (CAR) dengan unexpected earnings (UE) ada yang bernilai positif dan ada yang bernilai negatif. Rata-rata (mean) dari variabel ERC adalah sebesar 0,0957494 yang menggambarkan bahwa data berada pada kisaran nilai 0,0957494. Standar deviasi menunjukkan nilai 0,32692119 yang menggambarkan keragaman data, dimana semakin besar standar deviasi terhadap nilai rata-rata, semakin beragam nilai data yang ada, sehingga data ERC pada penelitian ini memiliki nilai yang beragam.

Leverage yang diukur dengan proksi debt to asset ratio (DAR) memiliki nilai terendah sebesar 0,13959 yang dimiliki oleh PT Indocement Tunggal Praksa Tbk. (INTP) dan nilai tertinggi sebesar 0,85931 yang dimiliki oleh PT Bank Tabungan Negara Tbk. (BBTN) Rata-rata (mean) dari variable leverage adalah sebesar 0,5149752 yang menggambarkan bahwa data rasio antara hutang dan total aset perusahaan sebesar $51,49 \%$. Standar deviasi menunjukkan nilai 0,21785428 sehingga diketahui bahwa data leverage pada penelitian ini kurang memiliki nilai yang beragam.

Earnings persistence (EP) memiliki nilai terendah sebesar -1,26100 yang dimiliki oleh PT Adhi Karya (Persero) Tbk. (ADHI) dan nilai tertinggi sebesar 6,58700 yang dimiliki oleh PT Tambang Batubara Bukit Asam (Persero) Tbk. (PTBA) Rata-rata (mean) dari variable EP adalah sebesar 0,6079032 yang menggambarkan bahwa rata-rata kemampuan perusahaan untuk mempertahankan jumlah laba yang diperoleh saat ini sampai masa yang akan datang adalah $60,79 \%$. Standar deviasi menunjukkan nilai 1,44303517 yang menunjukkan bahwa data earnings persistence pada penelitian ini memiliki nilai data yang beragam.

Size yang diukur dengan proksi logarithm natural total assets memiliki nilai terendah sebesar 29,17452 yang dimiliki oleh PT Matahari Department Store Tbk. (LPPF) dan nilai tertinggi sebesar 34,55919 yang dimiliki oleh PT Bank Mandiri (Persero) Tbk. (BMRI) Rata-rata (mean) dari variable size adalah sebesar 31,5083613, dari total sampel yang ada, terdapat 12 perusahaan yang dianggap sebagai perusahaan yang memiliki ukuran besar karena size di atas rata-rata. Standar deviasi menunjukkan nilai 1,44023014 yang menggambarkan keragaman data, dimana semakin besar standar deviasi terhadap nilai ratarata, semakin beragam nilai data yang ada.

Growth yang diperoleh melalui pertumbuhan aset memiliki nilai terendah sebesar 0,00619 yang dimiliki oleh PT Indocement Tunggal Praksa Tbk. (INTP) dan nilai tertinggi sebesar 1,01234 yang dimiliki oleh PT Waskita Karya (Persero) Tbk. (WSKT) Rata-rata (mean) dari variable growth adalah sebesar 0,1704219 yang menggambarkan bahwa data berada pada kisaran nilai 0,1704219. Standar deviasi menunjukkan nilai 0,19418943 sehingga disimpulkan bahwa data growth yang pada penelitian ini memiliki nilai yang beragam.

Free cash flow (FCF) sebagai variabel moderasi (SIZEFCF) dan (GRWFCF) yang memengaruhi hubungan size dan growth terhadap earnings response coefficient (ERC) memiliki nilai terendah sebesar $-0,05450$ yang dimiliki oleh PT Adhi Karya (Persero) Tbk. dan nilai tertinggi sebesar 0,63295 yang dimiliki oleh PT Matahari Departement Store Tbk. Rata-rata (mean) dari variable FCF adalah sebesar 0,1616348 yang menggambarkan bahwa data berada pada kisaran nilai 0,1616348 . Standar deviasi menunjukkan nilai 0,14828189 sehingga diketahui data variabel free cash flow pada penelitian ini memiliki data yang kurang beragam.

\section{Evaluasi Model Struktural (Inner Model)}

Evaluasi model struktural bertujuan untuk menjelaskan seberapa besar kemampuan model dalam menerangkan variasi variabel dependen. Berdasarkan hasil output WarpPLS lampiran diperoleh nilai $R$-Squared sebesar 0,51 memiliki arti bahwa $51 \%$ variasi dari ERC dapat dijelaskan oleh variabel leverage, earnings persistence, size, dan growth, serta variabel moderasi free cash flow. Sisanya $49 \%$ dijelaskan oleh variabel lain diluar model penelitian. Nilai adjusted $R$-Squared sebesar 0,387 memiliki arti bahwa 38,7\% variasi dari ERC dapat dijelaskan oleh variabel leverage, earnings persistence, size, dan growth, serta variabel moderasi free cash flow. Nilai $Q$ Squared pada variabel ERC adalah sebesar 0,430 $>0$ yang dapat diartikan bahwa model tersebut mempunyai predictive relevance. 


\section{Evaluasi Model Struktural (Inner Model)}

Evaluasi model struktural bertujuan untuk menjelaskan seberapa besar kemampuan model dalam menerangkan variasi variabel dependen. Berdasarkan hasil output WarpPLS lampiran diperoleh nilai $R$-Squared sebesar 0,51 memiliki arti bahwa $51 \%$ variasi dari ERC dapat dijelaskan oleh variabel leverage, earnings persistence, size, dan growth, serta variabel moderasi free cash flow. Sisanya $49 \%$ dijelaskan oleh variabel lain diluar model penelitian. Nilai adjusted $R$-Squared sebesar 0,387 memiliki arti bahwa 38,7\% variasi dari ERC dapat dijelaskan oleh variabel leverage, earnings persistence, size, dan growth, serta variabel moderasi free cash flow. Nilai $Q$ Squared pada variabel ERC adalah sebesar 0,430 $>0$ yang dapat diartikan bahwa model tersebut mempunyai predictive relevance.

\section{Penilaian Overall fit}

Berikut hasil pengujian evaluasi model struktural WarpPLS 6.0

Tabel 1.0

Hasil Evaluasi Model Struktural

\begin{tabular}{|l|l|l|l|}
\hline Struktural Item & Kriteria Fit & Nilai Output & Hasil \\
\hline Average Path Coefficient (APC) & $\mathrm{P} \leq 0,05$ & $\mathrm{P}=0,038$ & Fit \\
\hline Average -Squared (ARS) & $\mathrm{P} \leq 0,05$ & $\mathrm{P}<0,001$ & Fit \\
\hline Average Adjusted -Squared (AARS) & $\mathrm{P} \leq 0,05$ & $\mathrm{P}<0,001$ & Fit \\
\hline Average Block VIF (AVIF) & $\leq 3,3$, namun nilai $\leq 5$ masih dapat diterima & $\mathrm{AVIF}=1,608$ & Fit \\
\hline Average Full Collinearity (AFVIF) & $\leq 3,3$, namun nilai $\leq 5$ masih dapat diterima & AFVIF $=1,924$ & Fit \\
\hline Tenenhaus Gof & $\begin{array}{l}\geq 0,10 \geq 0,25 ; \text { dan } \geq 0,36 \text { (Kecil, } \\
\text { menengah, dan Besar) }\end{array}$ & 0,714 & Large (Besar) \\
\hline Sympson's Paradox Ratio (SPR) & $\begin{array}{l}\text { Idealnya }=1 \text { namun nilai } \geq 0,7 \text { masih dapat } \\
\text { diterima }\end{array}$ & SPR $=0,833$ & Fit \\
\hline R-Squared Contribution Ratio (RSCR) & $\begin{array}{l}\text { Idealnya }=1 \text { namun nilai } \geq 0,7 \text { masih dapat } \\
\text { diterima }\end{array}$ & RSCR $=0,992$ & Fit \\
\hline Statistical Suppression Ratio (SSR) & Harus $\geq 0,7$ & SSR $=0,833$ & Fit \\
\hline $\begin{array}{l}\text { Nonlinear Bivariate Causality Direction } \\
\text { Ratio } \text { (NLBCDR) }\end{array}$ & Harus $\geq 0,7$ & NLBCDR $=0,750$ & Fit \\
\hline
\end{tabular}

\section{Pengujian Hipotesis}

Analisis model struktural menghasilkan nilai estimasi hubungan kausal antar variabel. Dari output yang dihasilkan, diperoleh persamaan struktural sebagai berikut:

\section{ERC = 0,20 LEV + 0,38 EP + 0,10 SIZE - 0,39 GRW + 0,30 FCF $*$ SIZE - 0,04 FCF*GRW, R ${ }^{2}=0,51$}

Tabel 2.0

Path coefficients

\begin{tabular}{|l|l|l|l|l|l|l|l|}
\hline & ERC & LEV & EP & SIZE & GRW & FCF*SIZE & FCF*GRW \\
\hline ERC & & 0,203 & 0,380 & 0,105 & $-0,385$ & 0,297 & $-0,045$ \\
\hline Ket. & & Positif & Positif & Positif & Negatif & Memperkuat & Memperlemah \\
\hline
\end{tabular}

Tabel 3.0

P values

\begin{tabular}{|l|l|l|l|l|l|l|l|}
\hline & ERC & LEV & EP & SIZE & GRW & FCF*SIZE & FCF*GRW \\
\hline ERC & & 0,111 & 0,008 & 0,272 & 0,007 & 0,033 & 0,400 \\
\hline Ket. & $\begin{array}{l}\text { Tidak } \\
\text { Sig. }\end{array}$ & Sig. & Sig. & Tidak Sig. & Sig, & $\begin{array}{l}\text { Tidak } \\
\text { Sig. }\end{array}$ \\
\hline
\end{tabular}


Tabel 4.0

Hasil Uji P-value Satu Arah

\begin{tabular}{|l|l|l|}
\hline Variabel & P-Value $($ Sig) & Kesimpulan \\
\hline LEV & 0,0555 & Tidak Tolak H0 \\
\hline EP & 0,004 & Tolak H0 \\
\hline SIZE & 0,136 & Tidak Tolak H0 \\
\hline GRW & 0,0035 & Tolak H0 \\
\hline FCF*SIZE & 0,0165 & Tolak H0 \\
\hline FCF*GRW & 0,200 & Tidak Tolak H0 \\
\hline
\end{tabular}

Sumber: Hasil Pengolahan Data WarpPLS 6.0

\section{Pembahasan}

\section{Pengaruh Leverage (LEV) terhadap Earnings Response Coefficient (ERC)}

Berdasarkan hasil pengujian, didapatkan hasil bahwa leverage yang diproksikan dengan debt to asset ratio tidak berpengaruh signifikan terhadap earnings response coefficient (ERC). Hasil penelitian ini menunjukkan bahwa leverage tidak memiliki cukup bukti berpengaruh terhadap ERC, dan leverage memiliki arah positif terhadap ERC. Hasil temuan ini sesuai dengan hasil penelitian D. E. Irawati, (2012) Hasanzade et al. ( 2013).

Leverage yang tidak memiliki cukup bukti berpengaruh terhadap ERC menunjukkan bahwa leverage bukan merupakan suatu hal yang signifikan untuk dipertimbangkan oleh investor dalam pengambilan keputusan berinvestasi. Hal ini menandakan bahwa investor hanya mempertimbangkan informasi laba saja, tanpa mempertimbangkan tingkat leverage perusahaan. Menurut Hasanzade et al., (2013) alasan lain adalah karena sebagian besar hutang yang terdaftar adalah hutang kepada anak perusahaan atau di dalam satu grup perusahaan yang sama, informasi hutang tersebut tercermin di dalam laporan keuangan perusahaan (balance sheet) dari tahun ke tahun, namun investor tidak bereaksi terhadap informasi tersebut dan mengabaikannya karena informasi hutang tersebut tidak relevan. Sehingga signal informasi leverage tidak memberikan sinyal good news ataupun bad news terhadap investor.

\section{Pengaruh Earnings Persistence (EP) terhadap Earnings Response Coefficient (ERC)}

Berdasarkan hasil pengujian, earnings persistence (EP) terbukti berpengaruh positif dan signifikan terhadap ERC. Hasil penelitian ini sejalan dengan hasil penelitian Mulyani et al.
(2007), Delvira dan Nelvirita (2013) Lumantobing dan Arfianti (2012).

Earnings persistence yang terbukti berpengaruh positif terhadap ERC menunjukkan bahwa semakin persisten atau permanen perubahan laba dari waktu ke waktu, maka semakin tinggi ERC karena kondisi ini menunjukkan bahwa manajer perusahaan yang berusaha menghasilkan laba besar dan persisten dari tahun ke tahun karena memiliki kepentingan pribadi yang ingin dicapai, sebagai contoh agar mendapatkan kompensasi dari hasil kinerjanya. Laba yang diperoleh perusahaan meningkat secara terus menerus akan direspons baik oleh para investor sehingga meningkat nilai ERC. Hal ini sesuai dengan signaling theory, dimana perusahaan memberikan sinyal-sinyal baik (good new) sehingga dapat diterima atau direspons oleh pasar maupun investor dengan baik. Hasil ini sesuai dengan teori Scott (2015) yang mengatakan bawa laba yang diperoleh perusahaan tersebut dapat meningkat terus menerus ataupun stabil di masa yang akan datang. Laba yang dilaporkan merupakan signal mengenai laba di masa yang akan datang, sehingga dapat membantu para pengguna laporan keuangan dalam memprediksi laba di masa yang akan datang berdasarkan signal yang diberikan perusahaan.

\section{Pengaruh Size (SIZE) terhadap Earnings Response Coefficient (ERC)}

Berdasarkan hasil pengujian yang dilakukan, size atau ukuran perusahaan tidak memiliki cukup bukti berpengaruh terhadap ERC, namun size menunjukkan arah positif terhadap ERC. Hasil penelitian ini sesuai dengan penelitian Arfan dan Antasari (2008), D. E. Irawati (2012), Rofika (2015), dan Suwarno, Tumirin, dan Zamzami (2017).

Size yang tidak memiliki cukup bukti berpengaruh terhadap ERC menunjukkan bahwa 
size bukan merupakan suatu hal yang signifikan untuk dipertimbangkan oleh investor dalam pengambilan keputusan berinvestasi. Peneliti menduga hal ini terjadi karena baik perusahaan besar maupun perusahaan kecil sama-sama memiliki kelebihan dan kekurangan, perusahan besar memiliki informasi yang lebih besar namun memiliki risiko yang juga besar, adapun perusahaan yang kecil memiliki informasi yang relatif lebih sedikit namun memiliki risiko yang juga kecil. Sehingga investor mengabaikan informasi mengenai size dalam mengambil keputusan berinvestasi.

\section{Pengaruh Growth (GRW) terhadap Earnings Response Coefficient (ERC)}

Berdasarkan hasil pengujian, growth atau pertumbuhan menunjukkan bahwa terbukti berpengaruh negatif dan signifikan terhadap ERC. Hasil penelitian ini sesuai dengan hasil penelitian Arfan dan Yani (2011) dan Palupi et al. (2017).

Arah pertumbuhan perusahaan negatif terhadap ERC merupakan hal yang tidak mudah dijelaskan. Namun setidaknya dapat dijelaskan dengan random walk theory (Ang, 1997:183 dalam Arfan dan Yani, 2011) yang menyatakan bahwa pergerakan harga saham tidak dapat diprediksi sehingga hampir tidak ada cara yang dapat digunakan untuk mengetahui arah dari harga saham di masa yang akan datang. Random walk theory mengusulkan bahwa pergerakan harga saham bersifat independen satu dengan yang lainnya dan tidak mengikuti suatu pola tertentu.

Arah negatif tersebut menunjukkan bahwa perusahaan yang memiliki tingkat pertumbuhan yang tinggi, dipersepsikan oleh pasar memiliki tingkat ketidakpastian tentang masa depan yang rendah sehingga nilai ERC rendah. Demikian juga sebaliknya perusahaan dengan nilai pertumbuhan rendah dipersepsikan oleh pasar memiliki tingkat ketidakpastian yang tinggi sehingga memiliki nilai ERC tinggi.

\section{Pengaruh Free Cash Flow (FCF) terhadap hubungan antara Size (SIZE) dengan Earnings Response Coefficient (ERC)}

Berdasarkan hasil pengujian yang dilakukan, size atau ukuran perusahaan yang dimoderasi oleh free cash flows (FCF) atau arus kas bebas terhadap ERC menunjukkan bahwa free cash flow terbukti berpengaruh signifikan memoderasi hubungan size dengan ERC. Arah positif yang ditimbulkan oleh variabel free cash flow saat berinteraksi dengan size terhadap ERC menunjukkan bahwa free cash flow memperkuat pengaruh antara size dengan ERC. Hasil temuan ini sesuai dengan hasil penelitian Arfan dan Yani (2011).

Secara individual, koefisien regresi size mendapat respons positif dari investor namun tidak berpengaruh signifikan. Akan tetapi, setelah berinteraksi dengan free cash flow, slope koefisiennya menjadi berpengaruh dan positif. Para investor yang berpengetahuan luas akan menggali semua informasi yang tersedia secara luas. Informasi tersebut menyebabkan para investor bereaksi secara cepat dan tepat atas informasi baru yang pada akhirnya menyebabkan penyesuaian harga saham secara cepat dan akurat. Dalam hal ini, informasi yang dimaksud adalah informasi tentang size dan free cash flow. Investor yakin pada size yang semakin besar dan memiliki free cash flow yang tinggi akan lebih bisa meningkatkan kesejahteraan mereka dengan harapan pemabagian dividen, terutama bagi para investor yang mempunyai perspektif jangka panjang untuk mendapatkan yield dari investasi yang dilakukannya, yaitu dengan melihat nilai investasinya. Hal ini sesuai dengan teori efisiensi pasar yang telah dijelaskan pada hipotesis sebelumnya.

Pengaruh Free Cash Flow (FCF) terhadap hubungan antara Growth (GRW) dengan Earnings Response Coefficient (ERC)

Berdasarkan hasil uji SEM yang dilakukan, growth (GRW) atau pertumbuhan perusahaan yang dimoderasi oleh free cash flows (FCF) bebas terhadap ERC menunjukkan bahwa variabel free cash flow tidak memiliki cukup bukti berpengaruh signifikan terhadap hubungan growth dengan ERC. Artinya besar atau kecilnya kas yang tersedia untuk pemegang saham atau investor tidak berdampak apapun terhadap hubungan growth dengan ERC.

Sama seperti hasil pengujian growth terhadap ERC yang setidaknya dapat dijelaskan melalui random walk theory. Menurut Malkiel (2019:24) random walk merupakan suatu langkah masa depan ataupun arah tujuan yang 
tidak dapat diprediksi berdasarkan aktivitas masa lalunya. Dalam interpretasi pasar pada modal, random walk dapat diartikan harga perubahan saham dalam jangka pendek tidak dapat diprediksi.

\section{Simpulan Dan Saran}

Berdasarkan hasil penelitian dapat diambil Simpulan penelitian ini menunjukkan bahwa leverage, size growth tidak terbukti berpengaruh terhadap earnings response coefficient, dan free cash flow tidak terbukti memperkuat pengaruh growth terhadap earnings response coefficient. Namun, earnings persistence terbukti berpengaruh positif terhadap earnings response coefficient, dan free cash flow terbukti memperkuat pengaruh size terhadap earnings response coefficient.

Saran yang dapat penulis berikan bagi perusahaan yaitu dapat melihat penelitian ini untuk melihat tanggapan pasar terhadap informasi laba yang dipublikasikan. Dengan demikian, perusahaan diharapkan dapat meningkatkan kinerja perusahaan karena aspek fundamental masih menjadi perhatian bagi investor dalam melakukan keputusan investasi.

Bagi investor dapat menentukan pilihan investasinya pada perusahaan yang menerbitkan sekuritas dengan nilai ERC yang besar. Dengan menginvestasikan dana pada perusahaan yang memiliki nilai ERC yang besar, diharapkan bahwa investor akan memeroleh return yang besar.

Bagi peneliti selanjutnya sebaiknya menggunakan variabel atau proksi yang lain yang lebih berkaitan dengan laba atau penjualan, karena ERC memiliki topik yang berkaitan erat dengan laba dengan harapan agar hasil lebih tepat dan akurat. Peneliti selanjutnya juga diharapkan dapat mengganti variabel moderasi.

Lalu peneliti selanjutnya sebaiknya menggunakan sampel yang homogen, seperti perusahaan manufaktur yang terdaftar di BEI agar hasil penelitian lebih tepat dan akurat atau dapat mengganti indeks yang memiliki saham yang liquid untuk diperdagangkan dengan memiliki jumlah perusahaan lebih banyak seperti perusahaan-perusahaan yang tergolong dalam indeks Kompas 100. Adapun sebaiknya juga menambahkan tahun pengamatan dan jendela waktu yang lebih panjang untuk mendapatkan hasil yang lebih akurat.

\section{Daftar Pustaka}

Arfan, M., dan Antasari, I. (2008), Pengaruh Ukuran, Pertumbuhan, dan Profitabilitas Perusahaan Terhadap Koefisien Respon Laba pada Emiten Manufaktur di Bursa Efek Jakarta, Jurnal Telaah \& Riset Akuntansi, Januari Vol. 1, No. 1.

Arfan, M., \& Yani, I. (2011), Pengaruh Arus Kas Bebas Terhadap Hubungan Antara Pertumbuhan dan Ukuran Perusahaan dengan Earnings Response Coefficients pada Perusahaan Manufaktur yang Terdaftar di Bursa Efek Indonesia, Jurnal Maksi, Januari Vol 11, No. 1.

Asnawi, S. K., \& Wijaya, C. (2016), Manajemen Keungan untuk Non Keuangan, Edisi 2, Jakarta: PT Raja Grafindo Persada.

Collins, D. W., \& Kothari, S. P. (1989), An Analysis of Intertemporal and CrossSectional Determinants of Earnings Response Coefficients, Journal of Accounting and Economics, Februari Vol. 11.

Delvira, M., \& Nelvirita. (2013), Pengaruh Risiko Sistematik, Leverage Dan Persistensi Laba Terhadap Earnings Response Coefficient (ERC). Jurnal Wahana Riset Akuntansi, April Vol. 1 No. 1.

Eisenhardt, K. M. (1989), Agency Theory: an Assessment and Review, Academy of Management Review, Januari Vol. 14 No. 1.

Febrianto, Rahmat \& Erna Widiastuty (2005), "Tiga Angka Laba Akuntansi Mana Yang Lebih Bermakna Bagi Investor?", Simposium Nasional Akuntansi VIII Solo

Ghozali, I. (2018), Aplikasi Analisis Multivariate dengan Program IBM SPSS 25, Edisi 9, Semarang: Undip. 
Ghozali, I., \& Latan, H. (2016), Partial Least Square: Konsep, Metode dan Aplikasi Menggunakan Program WarpPLS 5.0, Semarang: Undip.

Gitman, L. J., \& Zutter, C. J. (2015), Principles of Managerial (Global), Singapore: Pearson Education.

Hartono, J. (2017). Teori Portofolio dan Analisis Investasi (11th ed.). Yogyakarta: BPFEYogyakarta.

Hasanzade, M., Darabi, R., \& Mahfoozi, G. (2013), Factors Affecting the Earnings Response Coefficient: An Empirical study for Iran, European Online Journal of Natural and Social Sciences, Vol. 2 No. 3.

Irawati, D. E. (2012), Pengaruh Struktur Modal, Pertumbuhan Laba, Ukuran Perusahaan dan Likuiditas Terhadap Kualitas Laba, Accounting Analysis Journal, November Vol. 3.

Jaswadi. (2004), Dampak Earnings Reporting Lags terhadap Koefisien Respon Laba, Jurnal Riset Akuntansi Indoensia, September Vol. 7 No. 3.

Jaya \& Sumertajaya (2008), Pemodelan Persamaan Struktural Dengan Partial Least Square, Prosiding Seminar Nasional Matematika dan Pendidikan Matematika, ISSN: 978-979-16353-1-8

Jensen, M. C., \& Meckling, W. H. (1976), Theory of the firm: Managerial Behavior, Agency Costs and Ownership Structure, Journal of Financial Economics, Vol. 3 No. 4.

Jonas, G. J., \& Blanchet, J. (2000), Assessing Quality of Financial Reporting. Accounting Horizons, September Vol. 14 No. 3.

Kallapur, S., \& Trombley, M. A. (1999), The association between investment opportunity set proxies and realized growth. Journal of Business Finance and
Accounting, May Vol. 26 (3\&4).

Lumantobing, R., \& Arfianti, R. I. (2012), Efek Perubahan Rasio Hutang Pada FaktorFaktor Yang Memengaruhi Earning Response Coefficient PerusahaanPerusahaan Bukan Tergolong Industri Sektor Jasa Keuangan Yang Terdaftar Di Bursa Efek Indonesia Periode Tahun 20002009, Jurnal Akuntansi, Februari Vol. 1 No. 1.

Malkiel, B. G. (2019), A Random Walk Down Wall Street: The Time-Tested Strategy for Successful Investing, Edisi 12, New York: W. W. Norton \& Company.

Mulyani, S., Asyik, N. F., \& Andayani. (2007), Faktor-Faktor Yang Mempengaruhi Earnings Response Coefficient Pada Perusahaan Yang Terdaftar di Bursa Efek Indonesia. Jurnal Akuntansi dan Auditing Indonesia, Juni Vol. 11 No. 1.

Murwaningsari, E. (2008). Faktor yang Mempengaruhi Earning Response Coefficient (ERC). Simposium Nasional Akuntansi XI, Juli.

Palupi, I. D., Wulandari, D. A., \& Safitri, D. A. (2017), Pengaruh Pengungkapan Informasi Proyeksi dan Tanggung Jawab Sosial Perusahaan Terhadap Koefisien Respons Laba, Riset Akuntansi dan Keuangan Indonesia, Vol. 2 No. 1.

Paramita, R. W. D., \& Hidayanti, E. (2013), Pengaruh Earnings Response Coeffisient (Erc) Terhadap Harga Saham, WIGA, Maret Vol. 3 No. 1.

Penman, S. H. (1991), An Evaluation of Accounting Rate-of-Return, Journal of Accounting, Auditing \& Finance, Vol. 6 No. 2.

Rofika (2015), Faktor-Faktor Yang Mempengaruhi Earnings Response Coefficient (ERC) Pada Perusahaan Manufaktur Yang Terdaftar Di Bursa Efek Indonesia 2012, Jurnal Akuntansi, April Vol. 3 No. 2. 
Ross, S. A., Westerfield, R. W., \& Jordan, J. B. D. (2010), Fundamentals of Corporate Finance, Edisi 9, New York: McGraw-Hill Companies, Inc.

Sandi, K. U. (2013), Faktor-Faktor yang Mempengaruhi Earnings Response Coefficient. Accounting Analysis Journal, Agustus Vol. 2 No. 3.

Scott, W. R. (2015), Financial Accounting Theory, Edisi 7, New York: Pearson Pretince Hall.

Subramanyam, K. R. (2014), Financial Statement Analysis, Edisi 11, New York: McGraw-Hill Education.

Sugiyono (2012), Metode Penelitian Kuantitatif Kualitatif dan $R \& D$, Jakarta: Rajawali Pers
Susanto, Y. K. (2012), Determinan Koefisien Laba, Jurnal Akuntansi dan Manajemen, Desmeber Vol. 23 No. 3.

Suwardjono. (2017), Teori Akuntansi Perekayasaan Laporan Keuangan, Edisi 3, Yogyakarta: BPFE.

Suwarno, Tumirin, \& Zamzami (2017), Influence of Size, Growth and Profitability of Company To Earnings Response Coefficient, International Journal of Advanced Research, Desember Vol. 5 No. 12.

Willett, R. J., Hwan Kim, Y., \& Jang, J. I. (2002), Default Risk as a Factor Affecting the Earnings Response Coefficient, SRSN. 


\section{LAMPIRAN}

Lampiran 1

Hasil Uji SPSS 25.0 Descriptive Statistics

\section{Descriptive Statistics}

\begin{tabular}{lr|r|r|r|r} 
& $\mathrm{N}$ & \multicolumn{1}{l}{ Minimum } & \multicolumn{1}{l}{ Maximum } & \multicolumn{1}{l}{ Mean } & \multicolumn{1}{c}{ Std. Deviation } \\
\hline ERC & 31 &,- 570281 & 1,451916 &, 09574887 &, 326920532 \\
\hline LEV & 31 &, 139590 &, 859310 &, 51497516 &, 217854285 \\
\hline EP & 31 & $-1,261000$ & 6,587000 &, 60790323 & 1,443035166 \\
\hline SIZE & 31 & 29,174520 & 34,559190 & 31,50836129 & 1,440230136 \\
\hline GRW & 31 &, 001690 & 1,012340 &, 17042194 &, 194189427 \\
\hline FCF & 31 &,- 054500 &, 632950 &, 16163484 &, 148281893 \\
\hline Valid N (listwise) & 31 & & & & \\
\hline
\end{tabular}

\section{Lampiran 2}

\section{Hasil Uji WarpPLS}

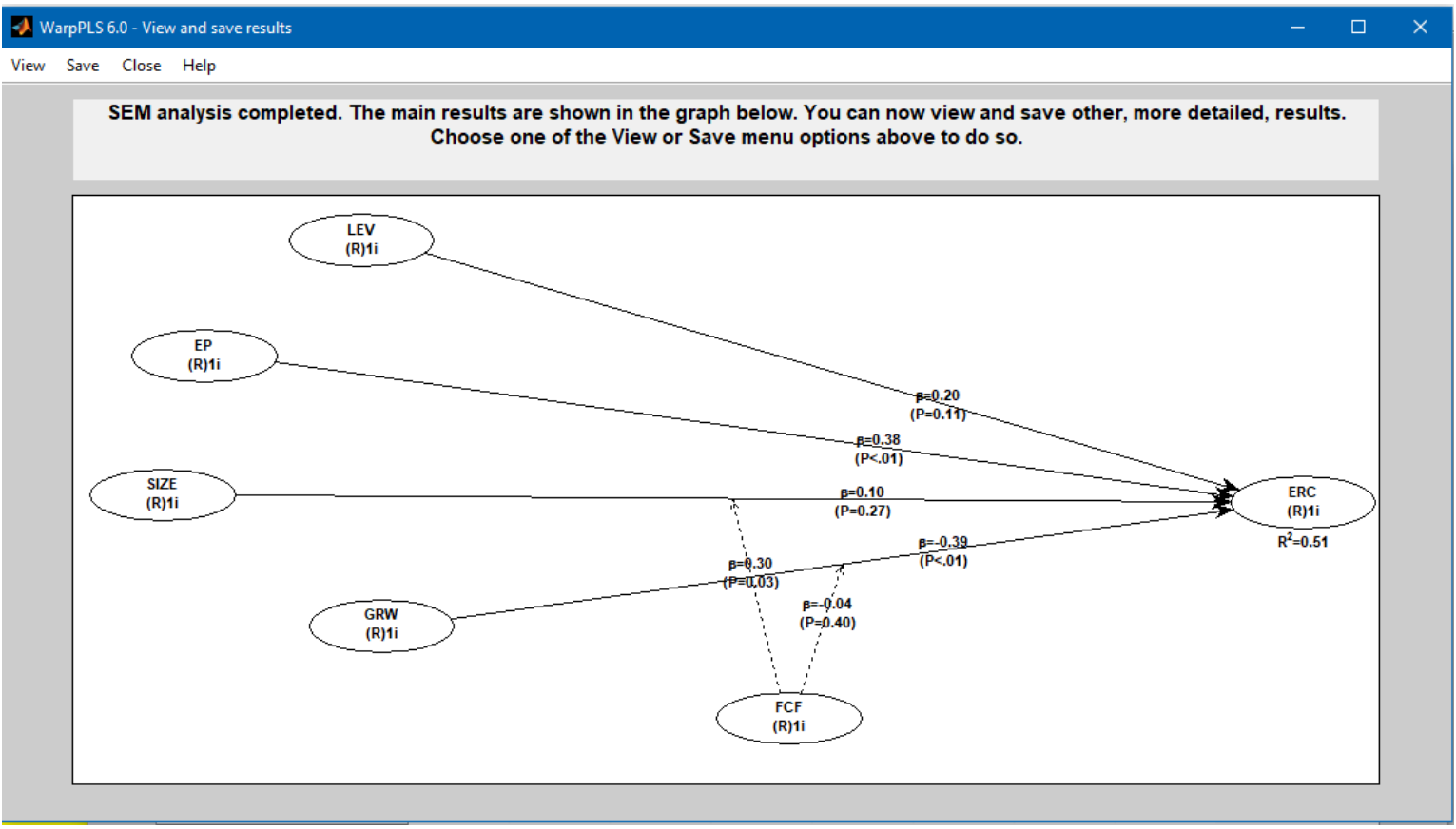




\begin{tabular}{|c|c|c|c|c|c|c|c|c|c|c|}
\hline \multicolumn{11}{|c|}{$\begin{array}{l}\text { A WarpPLS } 6.0 \text { - Path coefficients and P values } \\
\text { Close Help }\end{array}$} \\
\hline \multicolumn{11}{|c|}{ Path coefficients } \\
\hline & & ERC & LEV & EP & SIZE & GRW & FCF & FCF*SIZE & $\mathrm{FCF}^{*} \mathrm{GRW}$ & \\
\hline & ERC & & 0.203 & 0.380 & 0.105 & -0.385 & & 0.297 & -0.045 & \\
\hline \multirow{2}{*}{\multicolumn{11}{|c|}{ LEV }} \\
\hline & & & & & & & & & & \\
\hline \multicolumn{11}{|c|}{ SIZE } \\
\hline \multirow{2}{*}{\multicolumn{11}{|c|}{$\begin{array}{c}\text { GRW } \\
\text { FCF }\end{array}$}} \\
\hline & & & & & & & & & & \\
\hline \multicolumn{11}{|c|}{ FCF*SIZE } \\
\hline \multicolumn{11}{|c|}{ FCF*GRW } \\
\hline \multicolumn{11}{|c|}{$P$ values } \\
\hline & & ERC & LEV & EP & SIZE & GRW & FCF & FCF*SIZE & $\mathrm{FCF}^{*} \mathrm{GRW}$ & \\
\hline & ERC & & 0.111 & 0.008 & 0.272 & 0.007 & & 0.033 & 0.400 & \\
\hline \multicolumn{11}{|c|}{ LEV } \\
\hline \multicolumn{11}{|c|}{ EP } \\
\hline \multirow{2}{*}{\multicolumn{11}{|c|}{$\begin{array}{l}\text { SIZE } \\
\text { GRW }\end{array}$}} \\
\hline & & & & & & & & & & \\
\hline \multirow{2}{*}{\multicolumn{11}{|c|}{$\begin{array}{c}\text { FCF } \\
\text { FCF*SIZE }\end{array}$}} \\
\hline & & & & & & & & & & \\
\hline \multicolumn{11}{|c|}{$\begin{array}{l}\text { FCF*SIZE } \\
F C F^{\star} G R W\end{array}$} \\
\hline
\end{tabular}

|

Model fit and quality indices

Average path coefficient $(A P C)=0.236, P=0.038$

Average R-squared (ARS) $=0.510, P<0.001$

Average adjusted R-squared (AARS) $=0.387, P<0.001$

Average block VIF (AVIF) $=1.608$, acceptable if $<=5$, ideally $<=3.3$

Average full collinearity VIF (AFVIF) $=1.924$, acceptable if $<=5$, ideally $<=3.3$

Tenenhaus GoF (GoF) $=0.714$, small $>=0.1$, medium $>=0.25$, large $>=0.36$

Sympson's paradox ratio $(S P R)=0.833$, acceptable if $>=0.7$, ideally $=1$

$R$-squared contribution ratio $(R S C R)=0.992$, acceptable if $>=0.9$, ideally $=1$

Statistical suppression ratio (SSR) $=0.833$, acceptable if $>=0.7$

Nonlinear bivariate causality direction ratio $(\mathrm{NLBCDR})=0.750$, acceptable if $>=0.7$

WarpPLS 6.0 - Latent variable coefficients

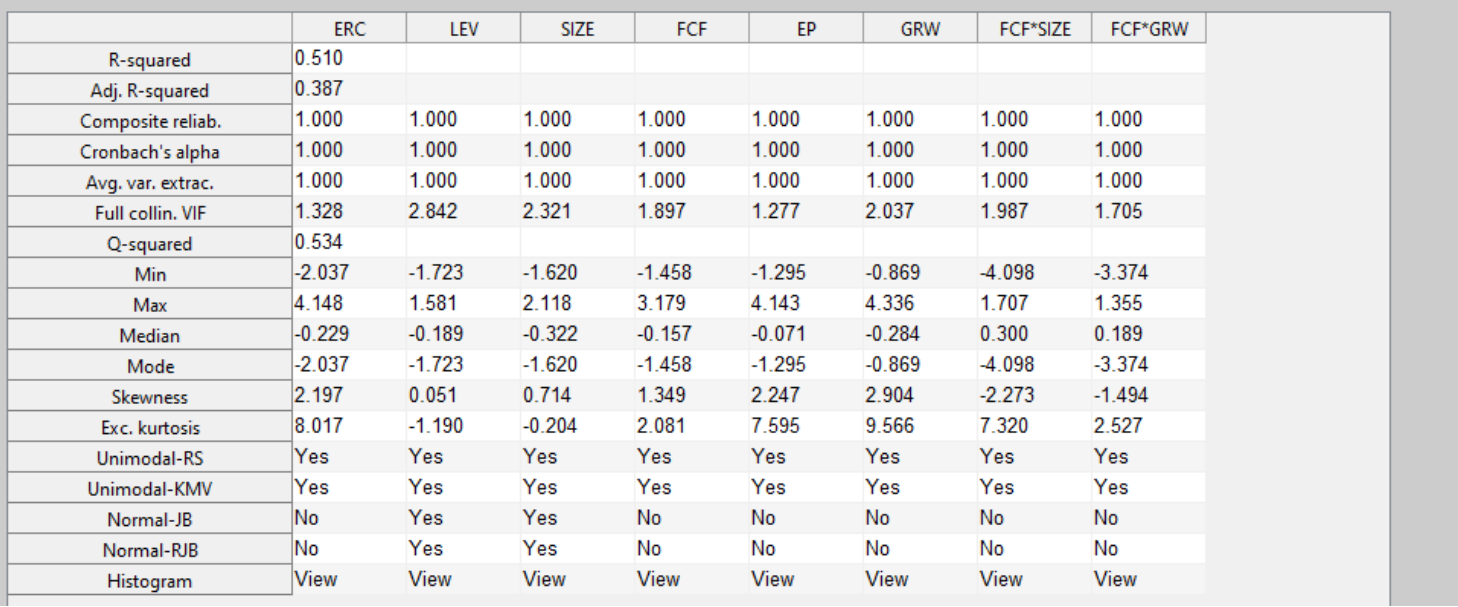

